\title{
BENTUK KOREOGRAFI TARI BEDANA HASIL REVITALISASI TAMAN BUDAYA PROVINSI LAMPUNG
}

\author{
Oleh: Eris Aprilia
}

(Pembimbing Tugas Akhir: Dr. Hersapandi., SST., MS dan Drs. D. Suharto, M. Sn)

(Jurusan Tari, Fakultas Seni Pertunjukan, Institut Seni Indonesia Yogyakarta)

Email: erisaprilia0@gmail.com

\begin{abstract}
RINGKASAN
Tari Bedana merupakan tari tradisi masyarakat Lampung yang berkembang di wilayah pesisir pada masa perkembangan agama Islam. Seiring perkembangannya tari Bedana sempat mengalami pasang surut, hingga akhirnya dilakukan revitalisasi dan ditampilkan kembali oleh Taman Budaya provinsi Lampung sebagai bentuk tari yang baru namun tetap berpijak pada nilai-nilai dan pola tradisi yang ada. Bagi masyarakat Lampung, tari Bedana merupakan tari pergaulan yang di dalamnya berisi filosofi pencerminan tata kehidupan masyarakat Lampung, yang digunakan sebagai simbol adat istiadat agama dan etika dalam pergaulan.

Penelitian ini bertujuan untuk menganalisis bentuk koreografi hasil revitalisasi. Bagaimana proses revitalisasi yang dilakukan Taman Budaya sehingga di dapatkan bentuk tari Bedana saat ini. Metode penelitian yang digunakan yaitu metode deskriptif kualitatif dengan pendekatan koreografi yang difungsikan untuk menganalisis kajian teks koreografi. Pendekatan koreografi merupakan cara mengkaji analisis teks koreografi suatu tarian dengan melihat aspek bentuk gerak, teknik gerak, gaya gerak, jumlah penari, jenis kelamin dan postur tubuh, struktur keruangan, struktur waktu, struktur dramatik, tata teknik pentas yang meliputi tata cahaya dan tata rias busana.

Hasil analisis koreografi menunjukkan bahwa tarian ini yang sebelumnya memiliki tiga belas ragam gerak, saat ini menjadi sembilan ragam gerak yang telah dibakukan. Gerak tersebut meliputi tahtim, khesek injing, khesek gantung, ayun, ayun gantung, belitut, jimpang, gelek, humbak moloh. Selain itu pada peralatan pendukung lainnya seperti busana dan aksesoris tari Bedana saat ini ditambahkan busana yang mencirikan daerah Lampung. Dari hal tersebut menunjukkan bahwa proses revitalisasi yang dilakukan oleh Taman Budaya dan instansi yang terkait telah membawa jati diri hingga menunjukkan ciri khas atau identitas daerah Lampung.
\end{abstract}

Kata kunci: Tari Bedana, Revitalisasi, Analisis Teks Koreografi 


\section{ABSTRACT}

Bedana dance is a traditional dance in Lampung that was developed on the coastline during the development era of Islam religion. As Bedana dance's development went through ups and downs causing revitalization and later, re-showcased by Cultural Park of Lampung Province as a new type of dance but holding on to the values and patterns of existing tradition. For the community in Lampung, Bedana dance is an associating dance that contains the philosophy of reflection of life order in the Lampung society and it is also being used as a symbol of religious customs and social ethics.

This research aims to expose the form of choreography resulting from revitalization - how the revitalization process was made by the cultural park before the new form of Bedana dance was obtained. The research methodology being used is a descriptive qualitative method with choreographic approach to analyze choreographic text study. Choreographic approach is a way of studying a dance's choreographic text analysis by observing the aspect of motion, motion techniques, style of motion, number of dancer, gender and body posture, spatial structure, time structure, dramatic structure, and staging techniques that involve lightning and fashion makeup.

The findings of choreographic analysis show that the previous dance has thirteen ranges of motion, which has now become nine standardized ranges of motion. Such motions cover tahtim, khesek injing, khesek gantung, ayun, ayun gantung, belitut, jimpang, gelek, humbak moloh. Other than the supporting equipment like Bedana dance's fashion and accessories, a fashion characterizing Lampung province has also been added. This shows that the revitalization process, made by Cultural Park of Lampung Province and other relevant agencies, has brought upon an identity that shows the special features or the identity of Lampung Province.

Key words: Bedana dance, Revitalization, Choreographic text analysis

\section{PENDAhULUAN}

\section{A. Latar Belakang Masalah}

Tari Bedana merupakan tari tradisi masyarakat Lampung yang mencerminkan tata kehidupan masyarakat Lampung, sebagai perwujudan simbolis adat istiadat, agama, etika, yang telah menyatu dalam kehidupan masyarakat (Junaidi Firmansyah dkk, 1996: 3). Tarian ini diperkirakan muncul sekitar abad ke-14 di daerah pesisir dan bersifat anoname, tetapi tari Bedana dapat dipahami sebagai tari yang tercipta karena adanya percampuran dua kebudayaan antara kebudayaan Lampung dan 
kebudayaan Arab (wawancara dengan Andi Wijaya, 18 februari 2017). Percampuran dua kebudayaan yang melekat menjadi satu kesatuan dan membentuk kebudayaan baru dapat disebut akulturasi. Menurut Sumaryono akulturasi adalah proses belajar unsur-unsur kebudayaan asing oleh suatu warga masyarakat, yang kemudian lambat laun kebudayaan asing tersebut terolah kedalam kebudayaan asli (Sumaryono, 2011: 23).

Terjadinya sebuah proses akulturasi, menjadikan Tari Bedana mempunyai ciri yang hampir sama dengan tari daerah lain di Nusantara dengan mayoritas penduduknya beragama Islam. Pada daerah yang mayoritas penduduknya beragama Islam, umumnya melahirkan tari dengan ciri, yakni gerak berfokus pada langkah-langkah kaki, diiringi dengan musik gambus/akordion, dan ritme pukulan kendang yang menjadi penentu gerak. Pada masyarakat Indonesia genre tari ini dikenal dengan beragam nama. Seperti pada masyarakat Melayu menyebutnya dengan sebutan Zapin. Secara etimologi kata Zapin berasal dari bahasa arab "al-zfn" yang mempunyai arti gerak kaki. Sebutan Zapin umumnya dijumpai di Sumatra Utara Riau dan Kepulauan Riau. Sedangkan Jambi, Sumatra Selatan, dan Bengkulu biasa menyebutnya Dana. Masyarakat Kalimantan cenderung memberi nama Jepin, di Sulawesi disebut Jipeng, di Maluku mengenal dengan nama
Jepen, di Nusa Tenggara dikenal dengan nama Dana-dani. Di sulawesi tenggara disebut Balumpa sedangkan di masyarakat Lampung genre ini dikenal dengan sebutan Bedana. (Direktur Jendral Kebudayaan. 2015: 5). Bedana mempunyai arti yang sama dengan Zapin yang berarti gerakan kaki. Menurut narasumber, kata Bedana berangkat dari kata kerja "dana" dan mendapat imbuhan "be". Penyebutan kata "dana" sebenarnya dari lirik syair ya dan ya dana yadadan ya dana yang sering disebutkan ketika menari Bedana (wawancara dengan Zubir Toyib, 18 februari 2017).

Melihat dari sejarahnya keberadaan Tari Bedana mulai muncul di daerah Lampung sekitar abad ke-14, pada saat itu diketahui keberadaan tari Bedana belum banyak dikenal, baru sebagian kecil khususnya di wilayah pesisir yang mendapat banyak pengaruh budaya Islam, seperti pesisir Telukbetung, Semangka, Kelumbaian, Putihdoh dan Kalianda (wawancara dengan Andi Wijaya, 18 februari 2017). Baru di awal kemerdekaan sekitar tahun 1950-an tari Bedana mulai eksis di masa itu, tari Bedana pada saat itu menjadi tari wajib bagi laki-laki untuk dipelajari, karena pada saat itu tari Bedana digunakan sebagai sarana tari pelengkap pesta adat (nyambai) di wilayah pesisir. Kemudian masuk di era tahun 1980-an nampak adanya suatu pergeseran, dimana pengaruh 
kebudayaan Eropa sangat digandrungi kaum muda pada saat itu. Hingga tahun 1985 tari Bedana semakin tenggelam karena adanya pengaruh globalisasi dan modernisasi dan mulai diketahui hanya sedikit kampungkampung adat yang masih ada regenerasinya, salah satunya yang masih berkembang dan bertahan pada saat itu di kampung Negeri Olok Gading daerah Telukbetung. Melihat keberadaan tari Bedana yang sudah mulai tenggelam dan mulai pudar eksistensinya, akhirnya Taman Budaya provinsi Lampung mengambil tindakan untuk merevitalisasi seniseni tradisi yang hampir punah, kegiatan tersebut mendapat apresiasi dan dukungan pemerintah, hingga mulai tahun 1988 tari Bedana dilakukan revitalisasi. merevitalisasi seni tradisi adalah untuk merangsang aktivitas dan kreativitas guna menumbuh kembangkan tari Bedana agar tidak terjadi kepunahan.

Berangkat dari paparan latar belakang di atas maka muncul pertanyaan bagaimana bentuk koreografi tari Bedana hasil revitalisasi Taman Budaya provinsi Lampung. Pertanyaan tersebut sebagai pokok permasalahan atau Fokus penelitian akan menganalisis bentuk koreografi tari Bedana atau teks tari hasil revitalisasi Taman Budaya Lampung. Menurut Lois Ellfeldt, koreografi adalah proses di dalam pemilihan dan pembentukan gerak menjadi suatu tarian (Ellfeldt, 1977: 12). Dalam revitalisasi koroegrafi tari Bedana yang dimaksud pemilihan dan pembentukan gerak atau upaya-upaya pencarian dan penemuan tertentu terkait dengan aspek-aspek tari yang telah hilang, berubah, atau pun yang masih dipertahankan dari tradisi aslinya.

Analisis koreografi tari Bedana secara sistematik akan dibedah menggunakan pendekatan koreografi. Pendekatan koreografi, difungsikan untuk menganalisis kajian teks koreografi. Teks koreografi adalah pemahaman mendeskripsikan atau mencatat secara analisis fenomena tari yang tampak dari sisi bentuk luarnya saja (Y. Sumandiyo Hadi, 2007: 23). Artinya, bahwa analisisi korerografi adalah sesuatu yang tampak, dapat di baca dan di analisis secara tekstual, sehingga susunan gerak tari itu secara detail dan rinci dapat dilihat secara kasat mata untuk dapat dikomunikasikan kepada penonton. Analisis teks koreografi pada suatu tarian dapat dilihat melalui: analisis bentuk gerak, analisis teknik gerak, analisis gaya gerak, analisis julmah penari, analisis jenis kelamin dan postur tubuh, analisis struktur keruangan, analisis struktur waktu, analisis struktur dramatik, analisis tata teknik pentas yang mencakup tata cahaya dan tata rias busana. Melalui analisis tekstual ini dapat dipahami sebuah bentuk artistik yang bermakna dan berfungsi sebagai identitas budaya suatu masyarakat, bahkan teks koreografi itu menjadi karakteristik daerah 
tertentu yang membedakan dengan daerah lain.

\section{PEMBAHASAN}

\section{A. Proses Revitalisasi}

Revitalisasi pertunjukan tradisional tari Bedana merupakan salah satu bagian dari usaha konservasi atau pelestarian seni tradisi. Revitalisasi menurut Kamus Besar Bahasa Indonesia adalah, proses, cara, perbuatan, menghidupkan dan menggiatkan kembali berbagai kegiatan-kesenian tradisional diadakan dalam rangka atau dalam kebudayaan lama (Depdiknas. 2001: 954). Revitalisasi seni pertunjukan tradisi memerlukan upaya yang keras, serta langkahlangkah strategi yang komprehensif untuk "menghidupkan" kembali kekuatan kesenian itu, sehingga ia mendapatkan daya atau vitalitas, serta "kehidupan" yang baru. Oleh karena itu, revitalisasi seni pertunjukan tradisi harus dilihat sebagai sebuah usaha menyeluruh yang saling terkait, yang melibatkan barbagai pihak (Y. Sumandiyo Hadi. 2011: 10).

Tujuan dari revitalisasi itu sendiri adalah: pertama, untuk mencegah tari Bedana mengalami kepunahan. Kedua, untuk mendapat bentuk baru yang dapat dijadikan embrio baru yang nantinya dapat merangsang aktifitas dan kreativitas guna menumbuh kembangkan seni tari khusunya Bedana. Ketiga, yaitu sebagai media pendidikan untuk pembentukan karakter individu peserta didik di daerah Lampung berupa mata pelajaran 'muatan lokal'. Jika sebelumnya pelajaran 'muatan lokal' hanya berisi tentang bahasa daerah Lampung, maka dewasa ini tari Bedana menjadi mata pelajaran 'muatan lokal'.

Revitalisasi dilakukan oleh Taman Budaya pada tahun 1988. Proses revitalisasi berlangsung dengan 3 tahap yaitu penggalian, penataan, dan sosiaisasi. Pertama tahap penggalian, penggalian tari Bedana dilakukan oleh beberapa tim dari Taman Budaya. Penggalian ditujukan untuk mendapat sumber objek dari narasumber dan dokumentasi penari Bedana asli yang langsung belajar dengan bangsa Arab. Tim pelaksana revitalisasi terdiri dari ketua Hafizi Hasan dengan Anggotanya djuwita Novrida, Agus Sugeng Muhadi, Eny Sriwini, dan I Nyoman Arsana. Selain itu yang bertanggung jawab dalam proses pelaksanaan tersebut adalah ketua Taman Budaya yang saat itu masih Moh. Asswans, S.H. (Wawancara dengan Nugraha Amijaya. 8 Februari 2017).

Kedua tahap penataan yaitu setelah penggalian dan mendapat data yang cukup maka mulai dibuat penataan baru dengan berpijak pada tradisi lama. Pada penataan mendapat hasil: dari 13 gerak dipadatkan menjadi 9 gerak. Adapun ke-13 gerak tari Bedana lama yaitu 1).Takzim, 2).Kesekh injing, 3).Lapah, 4).Motokh, 5).laju/motokh laju, 6).Mulokh/motokh 7).Pecoh, 8).Susun 
sirih, 9).Kesekh gantung, 10).Motokh mejong, 11).Lapah mundokh, 12).Tahtim, 13).Tahto. Pemadatan ke 9 gerak yaitu 1).Tahtim, 2).Khesek Injing, 3). Khesekh Gantung, 4). Ayun,5). Ayun Gantung, 6). Jimpang ,7). Humbak Moloh, 8). Belitut, 9).Gelek.

Pola lantai sebelumnya penari Bedana melakukan pola lantai seperti Alif dalam Arab, pola lantai seperti huruf Alif penari hanya melakukan lintasan yang dilalui yaitu bolakbalik depan belakang. Dari revitalisasi kini pola lantai dibuat dengan berbagai arah hadap dan mulai mengacu pada konsep koreografi yang berkembang saat ini. Pola lantai yang banyak digunakan adalah pola lantai melingkar, horizontal, diagonal, vertikal.

Durasi pertunjukkan pada awalnya tari Bedana bisa dilakukan ber jam-jam dari malam hari hingga pagi dini hari, hal tersebut dilakukan karena tari Bedana dahulu terkait dengan acara nyambai di daerah pesisir. Namun saat ini tari Bedana hanya ditampilkan sekali saja oleh beberapa penari yang sudah terlatih sebelumnya. Biasanya ditampilkan pada acara acara pernikahan, acara festival, acara peresmian dan lain sebaginya. Pada pementasan tari Bedana hanya membutuhkan waktu kurang lebih 7 menit saja.

Pada tempat pertunjukan, karena dahulu biasa ditampilkan pada saat serangkaian acara nyambai, biasanya tari Bedana ditarikan di halaman rumah pemilik hajat atau di dalam rumah yang memiliki ruangan yang cukup luas. Tempat menari Bedana dahulu hanya beralaskan tikar atau karpet dan menari di atas alas tersebut. Namun saat ini tari Bedana dapat dipentaskan di panggung, di lapangan atau tempat lainnya.

Pada busana dahulu tidak ada patokan atau diseragamkan ketika akan menari Bedana, umumnya setiap masyarakat pasti memiliki kostum yang digunakan karena kostum tersebut sangat sederhana yang biasa digunakan sehari-hari kostum yang digunakan bersifat Islami seperi pakaian yang dipakai ketika akan shalat. Saat ini penataan kostum mulai diseragamkan. Pemilihan kostum digunakan warna-warna yang cerah dan ditambahkan aksesoris yang menunjukkan ciri khas daerah Lampung.

Pada alat musik dahulu digunkan alat musik Gambus lunik (gambus anak buha), Ketipung, Karenceng (terbangan), saat ini terdapat tambahan alat musik gong kecil, bahkan untuk lebih semaraknya dapat pula dipakai alat-alat musik modern, seperti: biola, accordion, dan lain lain. Pada tahap penataan dari proses revitalisasi menjadikan tari Bedana dibakukan. Dibakukan sama halnya dengan dipatenkan atau ditetapkan dan disetarakan dengan harapan agar tari Bedana menjadi sama diseluruh daerah Lampung.

Ketiga, proses sosialisasi yaitu proses dimana tari Bedana diperkenalkan dan 
diajarkan ke masyarakat luas. Dalam proses ini Taman Budaya dibantu Dinas Pendidikan dan Kebudayaan propinsi Lampung dalam mensosialisasikan seni tradisi pada ranah pendidikan.

\section{B. Analisis Teks Koreografi}

Kajian Teks koreografi adalah pemahaman mendeskripsikan atau mencatat secara analisis fenomena tari yang tampak dari sisi bentuk luarnya saja. Bentuk koreografi tari Bedana dalam kajian teksnya, mengupas tentang analisis bentuk gerak, teknik, dan gaya. Artinya, bahwa analisis koreografi adalah sesuatu yang tampak, dapat di baca dan dianalsisis secara tekstual, sehingga susunan gerak tari itu secara detail dan rinci dapat dilihat secara kasat mata untuk dapat dikomunikasikan kepenonton. Selain ketiga analisis tersebut, analisis koreografi juga akan melihat dari segi analisis jumlah penari, analisis jenis kelamin dan postur tubuh, analisis struktur ruang, analisis struktur waktu, analisis struktur dramatik, dan analisis tata teknik pentas.

Analisis bentuk adalah analisis terhadap proses yang mewujudkan atau mengembangkan suatu bentuk dengan berbagai pertimbangan prinsip bentuk menjadi sebuah wujud gerak tari. Prinsip-prinsip bentuk yang perlu dianalisis antara lain kesatuan, variasi, repetisi atau ulangan, transisi atau perpindahan, rangkaian, perbandingan dan klimaks. (Y. Sumandiyo Hadi. 2003: 7284). Teks koreografi tari Bedana hasil revitalisasi Taman Budaya propinsi Lampung adalah kesatuan bentuk gerak yang berpijak dari tari Bedana tradisi. Secara garis besar susunan tari Bedana hasil revitalisasi yaitu dibagi dalam tiga bagian: bagian awal, tengah, dan akhir. Pembagian tari Bedana hasil revitalisasi dibagi berdasarkan lagu. Lagu tersebut adalah lagu penayuhan, lagu Bedana dan lagu mata kipit. Ciri khas dalam tari Bedana adalah Setiap hitungan $8 \times 8$ tari Bedana ditandai dengan keprakan rebana. Kesatuan estetis dari bentuk penyajian yang tersususn dalam tiga bagian tentu memiliki variasi, repetisi atau ulangan, transisi atau perpindahan, rangkaian, perbandingan dan klimaks.

Dalam proses penyusunan motif-motif gerak menjadi kalimat gerak tari atau koreografi perlu dilakukan variasi. Dilakukannya variasi adalah untuk memunculkan dinamika di dalam tari. Dalam tari Bedana variasi dapat dilihat dari penggunaan arah hadap, tinggi, rendah, level, tempo, dan pergantian posisi penari. Variasi arah hadap yang sering dilakukan yaitu arah hadap depan, berhadapan, saling membelakangi. Pada variasi level terdapat level medium (sedang), dan level low (rendah), pada variasi tempo terdapat tempo cepat dan 
sedang. Tempo cepat biasanya ditandai dengan bunyi keprakan rebana, sedangkan tempo sedang biasanya dilakukan setelah keprakan rebana dan mulai masuk musik lagu yang terdiri dari lagu Penayuhan, Bedana dan mata Kipit. Pada pergantian posisi yang banyak dilakukan penari Bedana adalah perpindahan penari depan-belakang, samping kanan, kiri, serong.

Pengulangan, mempunyai pengertian yang luas antara lain berarti suatu "pernyataan kembali" (restate),penguatan kembali (reinforce), gema-ulang (re-echo), rekaptulasi (recaptulation), revisi (revisi), mengingat kembali (recall), dan mengulang kembali (reiteratestresses) (Jcqueline Smith. 1985: 46-47). Pada tari Bedana hampir setiap ragam gerak mengalami pengulangan gerak, pengulangan setiap ragam bisa dilakukan dua sampai empat kali kali pengulangan. Hal ini diarenakan dalam tari Bedana keseluruhan rangkaian tari yang dilakukan selama enam menit hanya menggunakan sembilan ragam pokok yang ada, sehingga hal tersebut memungkinkan dalam keseluruhan rangkaian tari Bedana semuanya terdapat pengulangan gerak.

Perpindahan transisi, adalah sambungan dari gerak satu ke gerak lainnya yang berbentuk pengikat atau penghubung antar gerak. Perpindahan transisi pada tari Bedana dilakukan 2x8 hitungan setelah melakukan gerak $8 \times 8$ hitungan seperti yang telah di jelaskan di atas sebelumnya. Contoh transisi yang dilakukan saat perpindahan transisi ini seperti gerak, tahtim, gelek, belitut, jimpang.

Rangkaian, dapat dianalisis sebagai sebuah kontinuitas, yang perlu diperhatikan agar dapat dirasakan sebagai sebuah pengalaman (Y. Sumandiyo Hadi. 2007: 28). Rangkaian harus mempertimbangkan kontinuitas menurut kebutuhan dan keutuhan bentuk gerak (Y. Sumandiyo Hadi. 2007: 28). Pada tari Bedana rangkaian adalah satuan dari penggambaran pergaulan muda-mudi, dalam hal ini pergaulan digambarkan dengan rangkaian gerak tari yang lincah yang ditopang dengan unsur gerak kaki, selain itu aspek yang mendukung rangkaian dalam tari Bedana terdapat ciri khasnya keprakan rebana. Keprakan rebana berfungsi sebagai penanda gerak setelah hitungan $8 \times 8$. Biasanya setiap keprakan rebana diisi dengan ragam gerak diantaranya: tahtim, belitut, jimpang, dan gelek. Umumnya ragam yang digunakan tersebut memiliki hitungan $1 x 8$. Sedangkan pada keprakan rebana jika dihitung adalah 2x8 hitungan, jadi motif motif yang disebutkan di atas biasanya ketika keprakan rebana gerak dilakukan 2 kali pengulangan. Selain ragam tersebut jarang sekali atau bahkan hampir tidak ada ditemui motif lainnya seperti khesek gantung, khesek injing, ayun, ayun gantung yang mempunyai hitungan $1 \times 4$ dilakukan 
ketika musik keprakan rebana. Hal ini dimungkinkan hitungan $1 \times 8$ yang dipergunakan adalah kesinambungan yang menjadi rangkaian yang utuh sehingga dapat dinikmati, dari pada motif yang mempunyai hitungan $1 \mathrm{x} 4$.

Klimaks Sangat berkaitan dengan penempatan suatu rangkaian atau kontinuitas gerak yang telah dibahas sebelumnya. Dalam sebuah tari atau koreografi klimaks dinikmati sebagai titik puncak dari perkembangan, serta memberi arti dari kehadiran "permulaan", "perkembangan" dan "penyelesaian" (Y. Sumandiyo Hadi. 2007: 29). Dalam tari Bedana sebelum klimaks ditandai dengan tahtim sembah, hal ini berkaitan karena sebelumnya pada permulaan juga ditandai dengan tahtim sembah. Setelah penari melakukan ragam tahtim sembah kemudian mulai masuk musik iringan rebana yang bertempo cepat secara berurutan. Klimaks yang mempunyai ritme tempo cepat biasanya didalam tari Bedana menandakan berakhirnya sebuah tarian.

Analisis teknik dapat dipahami sebagai cara mengerjakan seluruh proses baik kegiatan fisik maupun mental yang memungkinkan para penari mewujudkan pengalaman estetisnya dalam sebuah komposisi tari, sebagaimana ketrampilan untuk melakukannya (Y. Sumandiyo Hadi. 2007: 29). Dalam hal teknik setiap penari harus menguasai seperti: teknik bentuk teknik medium dan teknik instrumen untuk membentuk sebuah komposisi tari. Analisis teknik bentuk, teknik medium dan teknik instrumen secara bentuk dilakukan penari dalam mewujudkan gerak dalam sebuah bentuk tari atau koreografi. Hal yang perlu dianalisis adalah bagian-bagian tubuh sikap badan, sikap kaki, sikap tangan,sikap kepala yang berupa pandangan atau arah hadap. Berikut beberapa gerak yang dalam tari Bedana yang dibagi berdasarkan bagian anggota tubuhnya.

\section{a. Badan}

Pada dasarnya sikap badan tari Bedana adalah badan sedikit condong kedepan. Kecondongan sikap badan menyesuaikan alunan langkah kaki yang terus bergerak mengalir sehingga membentuk ciri yang mendayu-dayu. Sikap badan tersebut sebenarnya hampir sama dengan tari yang berunsur Zapin di daerah lain di Nusantara. Namun, dalam tari Bedana hasil revitalisasi di daerah Lampung sikap badan condong kedepan masih dilakukan walaupun tidak begitu nampak.

b. Kaki

Teknik kaki dalam tari Bedana mengenal langkah steep. Langkah steep adalah sebutan ketika kaki melangkah maju secara double. Contohnya pada motif tahtim ketika 
hitungan "tu" kaki kanan maju ke depan selanjutnya "e" kaki kiri maju ke depan dan "juh" kaki kanan kembali maju ke depan. Mendak, yakni sikap merendahkan anggota tubuh dengan tumpuannya yaitu kaki. Gantung, yakni kaki ditekuk sejajar lutut dan menggantung. Jinjit, biasanya sikap jinjit dilakukan salah satu kaki sedangkan kaki yang lain sebagai tumpuannya, contohnya pada motif khesek injing, pada hitungan tiga kaki kiri menapak sedangkan kaki kanan jinjit.

\section{c. Tangan}

Sikap tangan pada tari Bedana dilakukan sangat sederhana, disebut tangan berkelai dan kimbang dalam bahasa Lampung, berkelai yaitu tangan yang mengayun secara bergantian. Sedangkan kimbang yaitu tangan yang dilakukan berbeda tidak bergantian.

\section{d. Kepala}

Bagian kepala hanya terdapat gerak tolehan. Gerak tolehan terlihat pada arah pandangan yang dilakukan penari. Arah pandangan dalam tarian ini lebih banyak menghadap ke arah depan namun ada bagian pandangan ke arah bawah dan ke arah samping yaitu ketika melakukan gerak khesek injing dan khesek gantung. Pada gerakan khesek injing pandangan menghadap kebawah pada hitungan ke tiga. Pada motif khesek gantung terdapat pandangan menghadap ke samping yaitu juga terdapat pada hitungan ketiga.

Analisis Gaya Gerak, Pengertian gaya selalu melekat pada sebuah tarian atau koreografi yang sedang dipertunjukan. Gaya atau style dalam pemahaman ini lebih mengarah pada bentuk ciri khas atau corak yang terdapat pada gaya gerakan (Y. Sumandiyo Hadi. 2014: 53). Ciri khas gaya juga berkaitan dengan latar belakang budayanya. Pada latar belakang budayanya tari Bedana mengandung gaya gerak tari Zapin arab yang berunsur keislaman. Gaya Zapin pada umumnya mempunyai ciri khas pada bentuk langkah kaki. Hal ini dapat dilihat dari semua motif tari Bedana lebih cenderung gerakan kaki, sedangkan gerakan tangan hanyalah berkelai atau mengayun tangan bergantian. Berdasarkan fungsi gaya dapat dibedakan menjadi dua jenis yaiitu arsetif style (inilah saya) dan emblemic style (inilah kami). Tari Bedana lebih cenderung mengarah pada sebuah representasi gaya emblem yang menyatakan inilah kami, hal tersebut menunjukan tari Bedana sebagai identitas yang memiliki gaya kelompoknya sendiri yang berbeda dengan daerah lain. Beberapa point yang membedakan tari Bedana dengan tari yang berunsur Zapin di daerah lain adalah pada gerak tari Bedana, tata busana dan musik serta syair lagu yang digunakan. 
Ciri khas tari Bedana yang membedakan dengan daerah lain adalah jika dahulu ciri khas tari Bedana terdapat pada penggunakan langkah kaki yang dilakukan penari yaitu kiri dan kanan secara bersamaan (seperti berkaca). Namun saat ini ciri khas tari Bedana terletak pada ragam yang dimilikinya, yaitu tari Bedana mempunyai 9 ragam gerak pokok. Selain itu pada kostum yang digunakan untuk membedakan tari Bedana dengan daerah lainnnya adalah penggunaaan kostum serta aksesoris khas daerah Lampung. Selain itu yang menjadi ciri khas Lampung dan dapat dikenali pada daerah lainnya adalah busana yang dikenakan berupa kain tapis. Kain tapis merupakan kain tenun khas daerah Lampung yang memiliki keunikan dan berbeda dengan tari di dearah lainnya. Syair lagu yang digunakan dalam tari Bedana menggunakan syair lagu berbahasa Lampung. Vokal bahasa Lampung menjadi ciri khas sendiri pada setiap lagu Lampung. biasanya syair lagu dinyanyikan dengan nada tinggi dan melengking, yang terdengar begitu ciri khas. Begitupula dengan instrumen tari Bedana, instrumen yang dipakai adalah gambus lunik yang merupakan ciri khas Lampung.

Analisis jumlah penari, Analisis jumlah penari dalam tari Bedana dikategorikan sebagai koreografi kelompok. Hal tersebut dikarenakan tidak ada patokan jumlah penari Bedana namun yang menjadi pijakan bahwa tari Bedana selalu ditarikan secara berpasangan, baik dua orang penari, empat orang penari, dan seterusnya. Analisis koreografi Tari Bedana dalam dokumentasi vidio Taman Budaya tahun 2004 dilakukan oleh empat penari yang terdiri dari dua penari perempuan dan dua penari laki-laki, secara koreografi analisis jumlah penari yang terdiri dari empat penari dapat dikatakan komposisi kelompok besar (large-group compositions). Dalam analisis jumlah penari berkelompok berpasangan dapat membentuk bebrapa fokus pusat perhatian. Pada tari Bedana penari biasanya selalu membuat formasi berpasangan focus on one point, fokus on two point atau fokus on four point. Focus on one point terlihat ketika keempat penari membuat pola lingkar dengan arah hadap kedalam lingkaran, selain itu dapat dilihat ketika penari membentuk formasi lurus diagonal, lurus vertikal, dan lurus horizontal. Fokus on two point dapat dilihat penari ketika membentuk formasi 2-2 saling berjauhan. Pada fokus on four point dilihat penari ketika membentuk pola trapesium 1-1-1-1.

Analisis jenis kelamin dan postur tubuh, dibedakan menjadi 2 jenis yaitu literal (bercerita) dan non literal (tidak bercerita). Pada tari Bedana hasil revitalisasi Analisis jenis kelamin dan postur tubuh lebih bersifat non literal (tanpa cerita). Analisis jumlah penari non literal tidak begitu mengikat sajian 
koreografi tersebut hanya mementingkan jumlah penari untuk mempertimbangkan komposisi kelompok yang berkaitan dengan keruangan (Y. Sumandiyo Hadi. 2007: 51). Dalam penari Bedana hasil revitalisasi menggunakan penari laki-laki dan perempuan. Sedangkan postur tubuh penari tari Bedana hasil revitalisasi umumnya ditarikan oleh muda-mudi (remaja). Pemilihan penari biasanya dilakukan dengan memilih postur tubuh yang hampir sama, misalnya tinggi lakilaki dan perempuan dengan tinggi badan yang sama Atau laki-laki lebih tinggi sedang kan perempuan lebih rendah namun tetap seimbang. Pada penari yang berbeda jenis kelaminnya, biasanya penggunaan karakter geraknya sedikit dibedakan, misalnya penari laki-laki cenderung melakukan gerakan dengan volume melebar atau luas sedangkan penari perempuan cenderung melakukan gerak dengan volume menyempit atau tertutup.

Struktur keruangan, Dalam analisis ruang terdapat ruang positif dan negatif. Ruang positif adalah ruang yang ditempati secara nyata oleh objek atau desain bentuk gerak, sedangkan ruang negatif adalah space kosong diantara objek-objek atau desain desain wujud positif (Y. Sumandiyo Hadi. 2007: 55). Pada tari Bedana ruang positif dan negatif tercipta ketika penari saling berhadaphadapan. Dalam hal tersebut terlihat struktur keruangan yang ditempati kedua bentuk tubuh penari-laki-laki dan perempuan hingga dapat muncul ilusi ruang lengkung seperti vas bunga. Selain itu ruang positif negatif tercipta ketika keempat penari berkumpul ditengah dan semua saling menghadap kedalam. Hal tersebut dapat muncul ruang negatif sebagai ilusi gambaran pola lingkaran. Pada point ini juga dianalisis tentang arah. Arah merupakan lintasan yang dilalui penari selama tarian berlangsung dalam ruang pentas. Dalam hal ini arah sering dipahami sebagai lintasan penari yang bergerak dari satu tempat ketempat lain hinga membentuk pola lantai atau desain lantai seperti lurus, zig-zak, atau melengkung.

Analisis Struktur Waktu, Pada tari Bedana hubungan gerak dengan iringan bersifat normatif. Artinya, gerak dan iringan mempunyai hubungan yang erat yaitu bahwa didalam tari Bedana hitungan musik sama dengan hitungan tari. Ciri khas dalam tari Bedana adalah instrumen keprakan rebana digunakan sebagai penanda gerak. Penanda gerak dialkukan pada hitungan tari dan musik setelah $8 \times 8$ hitungan. Setelah keprakan rebana bisanya masuk lagu pengiring tari Bedana. Namun pada bagian terakhir tari Bedana biasanya penanda gerak dilakukan setelah hitungan $2 \times 8$. Keprakan rebana digunakan sebagai penaik tempo, karena penggunaan alat musik rebana dibukul dengan ritme tempo cepat selama $2 \times 8$ hitungan. 
Analisis struktur dramatik merupakan analisis yang mengidentifikasi sebuah pertunjukan baik koreografi yang bersifat literal maupun nonliteral. Tari Bedana termasuk dalam tari yang bersifat non literal atau tidak bercerita. Namun, unsur dramatik pada tari Bedana dapat digambarkan dalam bentuk penyajiannya melalui pengembanganpengembangan motif gerak. Pada penyajian tari Bedana yang menjadi pembeda yaitu adanya awal dan akhir, pada bagian awal ditandai menggunakan motif gerak tahtim sembah awal. Sedangkan pada bagian akhir menggunakan motif tahtim sembah akhir. Sedangkan untuk membentuk suatu klimaks dibagian tengah dibangun dengan menggunakan pengembangan motif gerak. Pada pengembangan motif-motif gerak banyak dilakukan pengulangan motif dan setiap hitungan gerak $8 \times 8$ ditandai dengan keprak rebana.

Analisis tata teknik pentas, merupakan salah satu bagian dari analisis koreografis yang mendukung sebuah garapan atau pertunjukan tari. Analisis tata teknik pentas meliputi tata cahaya, tata rias dan busana, serta properti atau perlengkapan lainnya.

Tata cahaya, Dalam pertunjukan tari Bedana tata cahaya yang digunakan sangat fleksibel disesuaikan dengan tari tersebut dipertunjukan. Misanya, jika dipertunjukan dalam procenium stage dapat ditarikan hanya dengan lampu general, jika di lapangan terbuka yang dipentaskan pada siang hari dapat dilakukan dengan penerangan cahaya matahari saja.

Tata rias busana, yang dikenakan tari Bedana merupakan sebuah kelengkapan pertunjukan yang mendukung sebuah sajian tari menjadi lebih estetis. Konsep tata rias dan busana pada tari Bedana mengacu pada identitas busana daerah Lampung. Tata busana yang digunakan penari wanita antara lain: Penekan rambut, Belattung tebak/sanggul malam, Gaharu kembang goyang/sual kira, Kembang melati/kembang melur, Subang giwir/anting-anting, Buah jukum/bulan temanggal, Bulu serattei/ bebitting, Gelang kano/gelang bibit, Kawai kurung, Tapis/betuppal. Sedangkan Busana laki-laki yang digunakan antara lain: Kikat akinan/peci sebagai ikat kepala, Kawai teluk belangal belah buluh, Kain bidak gantung/betumpal sebatas lutut, Bulu sarattei/ bebiting.

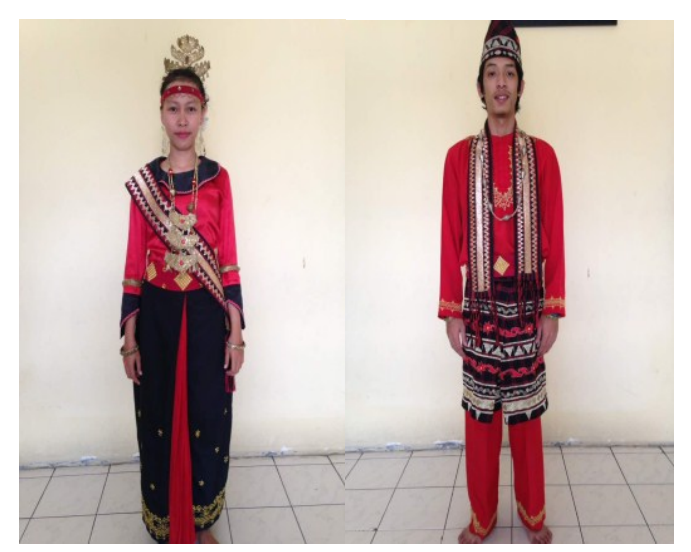

Foto kostum tari Bedana 


\section{PENUTUP}

Pada penelitian ini dapat disimpulkan bahwa tari Bedana merupakan tari tradisi masyarakat Lampung yang usianya cukup tua, diketahui muncul sekitar abad ke 14 di sekitar wilayah pesisir. Seiring dengan perkembangannya tari Bedana mengalami pasang surut hingga di tahun 1988 tari Bedana dilakukan revitalisasi oleh Taman Budaya provinsi Lampung. Revitalisasi berasal dari kata (revitalization) yang artinya suatu cara memperbaiki vitalitas (restore the vitality) atau memberi "kedidupan baru" (to impart new life). Upaya revitalisasi yang dilakukan Taman Budaya adalah memberi daya hidup pada tari Bedana untuk menghindari kepunahan.

Sebagai suatu langkah memperbaiki vitalitas dan memberi kehidupan baru pada tari Bedana, revitalisasi dilakukan Taman Budaya dengan bebrapa tahap yaitu: tahap penggalian, tahap penataan, dan tahap sosialisasi. Tahap penggalian tari Bedana dilakukan dengan mencari sumber informasi tentang data tertulis, lisan maupun bentuk karya tari Bedana lama. Setelah informasi cukup selanjutnya masuk pada tahap penataan, tahap penataan dilakukan dengan cara eksplorasi terhadap bentuk koreografi tari Bedana lama hingga ditemukan bentuk koreografi tari Bedana saat ini. Bentuk koreografi tari Bedana saat ini adalah mempunyai 9 motif gerak yang telah dibakukan. Pada proses penataan terhadap tari Bedana juga ditambahkan penegasan pada pemakaian aksesoris khas Lampung. Hal tersebut dilakukan dengan tujuan tari Bedana dapat menjadi sebuah tari yang mencirikhaskan daerah Lampung serta dapat menjadi identitas yang berbeda dengan daerah yang lain. Selanjutnya setelah tahap penataan selesai dilakukan tahap sosialisasi. Tahap sosialisasi merupakan tahap yang dilakukan untuk menghidupkan kembali tari Bedana. Tahap tersebut dilakukan dengan cara pembelajaran pada sanggar-sanggar tari maupun di ranah pendidikian (SD,SMP,SMA). Metode sosialisasi dengan cara pembelajaran merupakan upaya yang tepat agar tari Bedana tetap dikenal meluas di kalangan generasi muda.

Dari proses revitalisasi didapatkan hasil teks koreografi tari Bedana hasil saat ini yaitu: tari Bedana dahulu mempunyai 13 motif saat ini dipadatkan menjadi mempunyai 9 motif gerak pokok yaitu, tahtim, khesek injing, jimpang, belitut, gelek, ayun, humbak moloh, ayun gantung, khesek gantung. Pada penari, dahulu tari Bedana ditarikan oleh dua penari laki-laki dan laki-laki saja. Saat ini penari Bedana dapat ditarikan oleh laki-laki dan perempuan, laki-laki dan laki-laki, perempuan dan perempuan dengan jumlah penari genap. Rias dan busana tari Bedana dahulu 
menggunakan busana yang sangat sederhana yaitu baju lengan banjang, celana lengan panjang dan penutup kepala. Saat ini busana tari Bedana ditata lebih menarik dengan penambahan aksesoris khas Lampung hal tersebut dilakukan untuk menambah ciri khas daerah Lampung agar berbeda dengan daerah lain. musik tari Bedana dahulu menggunakan alat musik: gambus lunik, rebana, ketipung, saat ini terdapat tambahan kerenceng dan gong kecil. Syair lagu tari Bedana sejak dulu berisi pantun dan nasihat. Namun adanya revitalisasi membagi syair lagu menjadi tiga bagian yaitu lagu penayuhan, Bedana dan mata kipit. Pola lantai sebelumnya yaitu hanya melakukan gerak satu arah seperti huruf Alif dalam bahasa Arab dan cara melakukannya bolak balik. Setelah revitalisasi tari Bedana dapat dilakukan berbagai pola lantai seperti melingkar, diagonal, sejajar, selang-seling, dan sebagainya.

Tari Bedana hasil revitalisasi saat ini membuat perubahan yang lebih baik. Dahulu tari Bedana hanya berkembang di wilayah pesisir, namun saat ini tari Bedana berkembang hampir di seluruh daerah Lampung. Tari Bedana hasil revitalisasi menjadi tarian yang diajarkan pada peserta didik untuk bahan pengajaran seni budaya muatan lokal. Selain itu karena hasil revitalisasi menerapkan pembakuan gerak untuk dapat dijadikan pijakan pada tari kreasi selanjutnya, maka saat ini peminat seni mempunyai peluang mengembangkan tari Bedana yang berpijak pada tari Bedana hasil revitaliasi. Contoh perkembangan tari Bedana kreasi saat ini yaitu Bedana Marawis, Bedana Kipas dan masih banyak lainnya.

\section{DAFTAR SUMBER ACUAN}

\section{A. Sumber Tercetak}

Depdiknas. 2001. Kamus Besar Bahasa Indonesia Edisi 3. Jakarta: Balai Pustaka.

Kementrian Pendidikan dan Kebudayaan. 2015. Tетu Zapin Nusantara 2015 (Zapin Merajut Jejak Pergaulan Budaya Nusantara). Jakarta: Direktorat Kesenian Direktorat Jendral Kebudayan Kementrian Pendidikan Dan Kebudayaan.

Ellfeldt, Lois. 1967. A Primer For Choreographers. California: Laguna Beach. Terjemahan Sal Murgianto dengan judul Pedoman Dasar Penata Tari. 1977. Jakarta: Lembaga Pendidikan Kesenian Jakarta.

Firmansyah, Junaidi dkk. 1996. Mengenal Tari Bedana Bandar Lampung. Cetakan ke-1. Bandar Lampung: Gunung Pesagi

Hadi. Y. Sumandiyo. 2007. Kajian Tari Teks dan Konteks. Yogyakarta: Pustaka Book Publisher.

2003. Aspek-Aspek Dasar Koreografi Kelompok. Yogyakarta: Lembaga Kajian Pendidikan \& Humaniora Indonesia (Elkapti). 

Bentuk-Teknik-Isi. Cetakan ke-3. Yogyakarta: Cipta Media.

Sumaryono. 2011. Antropologi Tari Dalam Perspektif Indonesia. Yogyakarta: Badan Penerbit ISI Yogyakarta.

\section{B. Narasumber}

Andi Wijaya, 40 tahun, penari tari Bedana di sanggar Angon Saka, desa Negri Olok Gading.

Nugraha Amijaya, 51 tahun, seniman tari bekerja di Taman Budaya Provinsi Lampung bagian Pelaksana Fungsional Seni Tari.

Saprudin Tanjung, 42 tahun, seniman tari, koreografer dan penari tari Bedana

Syarifuddin, 57 tahun, sebagai ketua atau pemilik sanggar Angon Saka yang melestarikan tari Bedana tradisi di desa Negri Olok Gading.

Titik Nurhayati, 54 tahun, seniman tari bekerja di Taman Budaya Provinsi Lampung bagian Pelaksana Fungsional Seni Tari

Zubir Toyib, 66 tahun, seniman khusus vocal tari Bedana Lampung tradisi, di Sanggar Angon Saka, Negri Olok Gading.

\section{Discografi}

Vidio dokumentasi tari Bedana Hasil Revitalisasi Taman Budaya Provinsi Lampung, tahun 2004, koleksi Taman Budaya Provinsi Lampung.
Vidio tari Bedana tradisi sebelum direvitalisasi, 11 Februari 2017, koleksi pribadi peneliti. 